\title{
The Distinguishing Characteristic of Task-based Language Assessment
}

\author{
Majeed Noroozi \\ Florida International University, Miami, USA \\ Seyyedmohammad Taheri \\ Texas A \& M University, College Station, USA
}

\begin{abstract}
Since its advent, the principles of Task-Based Language Teaching have been extended to assessment giving rise to Task-Based Language Assessment. Despite the growing body of research on the efficacy of TaskBased Language Teaching in instruction, the application of the assessment based on the tenets of Task-Based Language Teaching has been mainly neglected in some studies owing to their lack of use of Task-Based Language Assessment to measure the effectiveness of Task-Based Language Teaching (viz., Li, et al., 2016). The present study emphasizes the importance of Task-Based Language Assessment and highlights the feature that distinguishes this type of assessment from other assessments. The study concludes that while the performance-referenced feature of Task-Based Language Assessment is an essential characteristic thereof, it is, in fact, the holistic and direct feature of Task-Based Language Assessment that distinguishes it from other assessments. The more the assessment measure is incorporated in the performance of assessment tasks, the more the assessment tasks are based on the tenets of Task-Based Language Assessment. Therefore, the holistic and contextualized assessment tasks improve the confidence with which language teachers could generalize the results of the assessment tasks to real-life situations.
\end{abstract}

Index Terms - task-based language assessment, task-based language teaching, assessment task, measure of performance

\section{INTRODUCTION}

Communicative Language Teaching (CLT) emerged in the mid-1970s in the UK as a reaction to the previous methods of language teaching, which deemed language as a pure linguistic system through which the phonological, lexical, and grammatical aspects of language were emphasized (Ellis, 2003; Samuda \& Bygate, 2008). The focus of Communicative Language Teaching was on the 'use' as opposed to the 'usage' of language, which is the ability to use language meaningfully and communicatively (Ellis, 2003). Task-Based Language Teaching and the concept of task gained popularity in response to the criticism of the Communicative Language Teaching's inefficiencies regarding its notional-functional syllabus. Communicative Language Teaching's notional-functional syllabus was still following a structure-based syllabus with a cumulative view of language in which the communicative activities revolved around discrete, pre-selected items where students would go through presentation of items in a controlled manner and ultimately practice them in free production (Bygate, 2016; Ellis, 2009). Task-Based Language Teaching took issue with the concept of structural syllabus' breaking language into small components and instead put forth the notion of learning through performing in the relevant context. Task-Based Language teaching is a subset of Communicative Language Teaching that emphasizes involving language learners in authentic language use through performing tasks (Ellis, 2012). In other words, Task-Based Language Teaching stresses the importance of experiential learning or learning through doing where the language is treated as a means to the end of achieving communicative goals.

Task-Based Language Teaching's tenets have been applied to assessing and evaluating language through Task-Based Language Assessment, an alternative form of assessment to replace large-scale Discrete-Skills Assessment (DSA) that emphasized rote memorization (Norris, 2016). In essence, Noroozi (2021) contends that the need for an alternative assessment gave rise to assessment paradigms, such as performance assessment and, subsequently, Task-Based Language Assessment (TBLA) (Mislevy, Steinberg, \& Almond, 2002; Norris, 2002), also known as Task-centered assessment (Brindley, 1994), Task-Based Language Performance Assessment (TBLPA) (Bachman, 2002), and taskbased assessment (Brown, Hudson, Norris, \& Bonk, 2002). More importantly, since discrete-point tests cause the issue of negative wash-back effect for Task-Based Language Teaching's performance-based instruction (Ellis, 2017), it was about time that Task-Based Language Teaching had a framework of assessment compatible with its instructional principles; Task-Based Language assessment filled that gap (Noroozi, 2021).

Task-Based Language assessment stresses the authenticity of assessment and language learners' use of the language ability rather than having a superficial knowledge of the language. Task-Based Language assessment requires language learners to use the language to achieve the assessment task's communicative goals (Norris, 2016). Wigglesworth (2008) contends that Task-Based Language Assessment is a type of performance assessment that emphasizes the performance 
of practical skills rather than simply abstract knowledge of the language. In essence, assessment tasks require language learners to use their 'cognitive skills and domain-related knowledge' in their performance in order to achieve the outcome (Norris, 2009).

The present study highlights the significance of Task-Based Language Assessment in that it is a compatible means of assessment to Task-Based Language Teaching. Additionally, the unique characteristic of this assessment framework that distinguished it from other types of assessment is examined.

Performance in Task-Based Language Assessment

It would be easier to highlight characteristics of Task-Based Language Assessment once a clear definition is put forth. Task-Based Language Assessment has been defined by Brindley (1994) as the process of evaluating the quality of learners' communicative performances obtained through their goal-directed, meaning-focused language use necessitating the combination of skills and knowledge. Brown (2004) defines task-based assessment as any assessment that requires language learners to be involved in a type of language behavior that triggers goal-oriented language use beyond the language testing context. Along the same lines, Brindley (2013) holds that Task-Based Language Assessment focuses on how well learners can use their language in order to achieve their real communicative goals, as opposed to examining their knowledge of language systems and structures. Therefore, Task-Based Language Assessment could be referred to as a holistic assessment procedure that uses assessment tasks as its principal instrument in order to elicit a meaning-focused, goal-directed language use typical of that of the target context from language learners while they attempt to accomplish the task outcome.

One of the main features of Task-Based Language Assessment, among others, is that it's performance-referenced (Shehadeh, 2012). Both performance assessment and task-based assessment highlight the significance of performance in assessment; however, the success or failure in accomplishing the task matters in Task-Based Language Assessment as opposed to performance assessment (Brown, 2004). The question arises as to what distinguishes Task-Based Language Assessment from other types of assessment, specifically other forms of performance assessment.

Long and Norris (2000) hold that the distinguishing characteristic of Task-Based Language Assessment is the use of performance as the construct of assessment. They argue that assessment tasks in Task-Based Language Assessment are not merely a means to elicit language samples; in fact, the performance of the assessment tasks is an end in itself. The focus of assessment, rather than testing the mastery of the language components, is to perform the task successfully. While performance is a significant part of Task-Based Language Assessment, the inference made from that performance is even more critical. One of the approaches to Task-Based Language Assessment makes inferences from the performance obtained from the task based on the underlying language ability. For instance, the performance obtained from the oral presentation of language learners in class can be analyzed based on the linguistics feature such as grammatical accuracy and vocabulary dominance. Ellis (2003) calls this approach to Task-Based Language Assessment the construct-centered approach. On the other hand, that performance could also be assessed based on the real-world criteria; that is, other non-linguistic factors could also be considered in the assessment of the language learners' performance, such as strategic and sociolinguistic techniques in conveying meaning (Long \& Norris, 2000). In this approach, what language learners can actually do in a particular context is important; in other words, the whole task itself is the construct of interest or the measure of assessment (Long \& Norris, 2000). In the same vein, Brown (2004) believes that even though performance is of great importance in Task-Based Language Assessment, it is the successful completion of the task that counts in the final assessment of tasks.

While performance is an essential part of Task-Based Language Assessment, it is not what distinguishes this assessment from other types of assessment. Task-Based Language Assessment's distinctive feature is the integration of the measure of the test taker's performance in the task itself, or in other words, the assessment task's directness of measurement (Ellis, 2003). Simply put, the assessment performance is the assessment measure in and of itself. Once the measure of task performance is inherent in the task, then the claim that it is the completion of the task that counts would be more meaningful.

\section{Characteristics of TASK-BASEd LANGUAGE AsSESSMENT}

Task-Based Language Assessment is a testing framework that uses assessment tasks as its principal unit, and that is based on the tenets of Task-Based Language Teaching (Shehadeh, 2012). Task-Based Language Assessment has the following main characteristics:

- It uses assessment tasks as the main instrument.

- It requires meaning-focused, goal-directed language use.

- The target measure (construct) of the assessment task is authentic, real-world behavior or real-world language use typical of the target context.

- The measure of test-takers' performance is incorporated into the assessment task (holistic).

- It is a criterion-referenced assessment commonly used as a formative assessment.

\section{A. Assessment Task as the Main Instrument}

The first feature of Task-Based Language Assessment highlights the distinguishing role of assessment tasks. Long and Norris (2000) hold that in a genuinely Task-Based Language Assessment, tasks have the central role of being the 
significant unit of analysis, which motivates item selection, test instrument construction, and the rating of task performance. Assessment tasks play a pivotal role in the design of tests in Task-Based Language Assessment. They require that test-takers use the language by combining both skill and knowledge and getting engaged in meaningful language communication (Brindley, 1994; Norris, 2002, as cited in Noroozi, 2018). As Task-Based Language Teaching uses pedagogical tasks, in the same vein, its relative assessment, Task-Based Language Assessment, necessitates the use of assessment tasks. The definition of the assessment task in the literature has been mainly derived from that which was put forth in Task-based Language Teaching. Ellis (2003) defines assessment tasks as tools used in the context of meaning-focused, goal-directed language use to elicit and evaluate learners' communicative performance. The communicative performance is elicited when language learners make an effort to achieve the non-linguistic outcome of the assessment task. Norris (2016) holds that assessment tasks require 'functional language use' to communicate meaningful ideas within a well-defined communitive setting (p. 239).

Assessment with tasks is quite different from Discrete-Skills Assessment (DSA), which only measures language learners' linguistic competence via the use of discrete and decontextualized test items. In essence, the use of Assessment tasks in Task-Based Language Assessment is conducive to assessing not only the linguistic competence of language learners but also their communicative competence. In other words, Task-Based Language Assessment transcends the scope of language knowledge and assesses language learners' ability to use language knowledge properly and effectively (Mislevy et al., 2002).

As for the choice of task and the measure of task performance, there are two major differences between Task-Based Language Teaching and Task-Based Language Assessment. As for the choice of the task, tasks both in teaching and testing should well cover and represent the construct or the domain being focused on (Noroozi, 2018). However, the importance and weight given to these criteria differ between Task-Based Language Teaching and Task-Based Language Assessment. In essence, the choice of the task is a more sensitive job in Task-Based Language Assessment compared to Task-Based Language Teaching since the choice of the task in Task-based Language Assessment has a direct impact on validity, which determines the credibility of scores (Ellis, 2003). Validity refers to the extent to which an assessment task successfully measures what it has been designed to measure. In other words, validity is the measure of correspondence between the intended use of an assessment use and what it actually measures (Ellis, 2003). It is imperative that the task used in Task-Based Language Assessment represent and cover the construct and the domain to be tested, while in Task-Based Language Teaching, it is desirable and satisfactory if the tasks to be taught have this feature (Noroozi, 2018). Besides, the measurement of task performance in Task-Based Language Assessment should be more explicit than in Task-Based Language Teaching. Developing such measures in assessing task performance in order to ensure reliability and validity is a painstaking process that requires time and expertise.

Assessment tasks need to have a clear-cut, explicit assessment criterion that indicates how to measure performance. This feature somewhat distinguishes Task-Based Language Assessment from Task-Based Language Teaching, where having an explicit performance measure is not required. Depending on the underlying criterion of the assessment task, there are two major approaches to Task-Based Language Assessment: (a) the assessment developed from the underlying ability or construct, (b) the assessment adapted from the holistic performance of the target task (Bachman, 2007; Brindley, 2013; Ellis, 2003; Long, 2015, as cited in Noroozi, 2018). The procedure of taking account of the underlying ability or the construct utilizes assessment tasks to provide information about test-takers' mastery of a certain underlying ability or construct of language. McNamara (1996) refers to this procedure as the weak version of the second language performance assessment since language takes precedence over task performance. In other words, tasks solely serve the purpose of eliciting language samples from learners for evaluation. The tests used in the ability/construct category of Task-Based Language Assessment are system-referenced, drawing on a psycholinguistic view of language use in their design. The underlying ability/construct approach focuses on linguistic components such as grammar, vocabulary, etc., in order to assess language learners' task performance. Long (2015) holds that defining the underlying ability or construct is a complicated issue of this procedure. The other Task-Based Language Assessment approach, which Ellis (2003, as cited in Noroozi, 2018) refers to as a work-sample approach, is more concerned with how learners can perform the task and what they can do in the assessment rather than with their language ability. In this approach, the whole task is the construct to be assessed rather than just the learners' linguistic proficiency (Long \& Norris, 2000). McNamara (1996) refers to this procedure as the strong version of the second language performance assessment where language is deemed as just a means to an end, the end being the completion of the task requirement. Brindley (2013) contends that it is the 'real-world' criteria that should be taken into account in assessing students' performance rather than the language criteria (p. 1). For instance, the ability to deliver a lecture requires more than just using the linguistic elements; thus, assessing non-linguistic elements should also be incorporated in the assessment. More specifically, one can be accurate in terms of grammar but not be able to convey the key points in delivering a lecture. Hence, task completion plays a significant role in this particular Task-Based Language Assessment approach. Ellis (2003) states that the assessment tasks based on this approach are often performance-referenced tests. However, this approach suffers from the transferability issue; that is, it is difficult to predict the real-life task performance based on a specific taskassessment performance (Long, 2015).

\section{B. Meaning-focused Goal-directed Language Use}


The second feature of Task-Based Language Assessment has to do with promoting meaning-focused, goal-directed language use. This feature requires that the assessment tasks focus on the meaning and purpose of the task in order to reach the communicative goals of the task. This characteristic is evident in pedagogical tasks where there is some gap to be filled or an outcome that the test-takers need to accomplish. Language learners need to use their linguistic and nonlinguistic repertoire in order to achieve the goal of the task and successfully perform it. Brindley (1994) argues that the goal-directed, meaning-focused language in Task-Based Language Assessment requires the integration of skills and knowledge; that is, language should serve the purpose of reflecting or achieving a particular skill, knowledge, or outcome. Given this criterion as the goal of Task-Based Language Assessment, language should not be used separately from its main function, which is getting across meaning or achieving a goal. In fact, this feature ensures that there is some non-linguistic purpose behind using the language. Therefore, language itself would not be the focus of the assessment; the main focus of the test-takers' attention is drawn to the ultimate goal that they achieve by accomplishing the task. Test-takers use both their linguistic and non-linguistic resources to successfully perform the task. Even though the test developers' purpose might ultimately be assessing the language as one of the important factors in accomplishing the task, the language would not be the center of the performance in assessment but a means to achieving the nonlinguistic outcome of the assessment task.

\section{Authentic Real-world Behavior/Language Use}

The underlying construct of the assessment task could be language ability/processing or the performance/behavior that represents a real-life situation. A closer look into this feature of Task-Based Language Assessment indicates that it is more related to the issue of the validity of the assessment where the tests are required to assess what they purport to assess. Task-Based Language Assessment requires that the type of performance in the assessment task be as close as possible to the real-life, authentic performance. As Ellis (2003) puts it, the task performance in assessment should closely correlate with the criterion performance, or what the test-takers would do in the real-life situation. Due to the limitation of test settings, it would be very idealistic to have an assessment task that perfectly correlates with the reallife task. Nonetheless, attempts should be made by task designers to approach as much as possible the performance typical of the real-life settings. The authenticity of the assessment tasks improves the generalizability of the assessment, which is as the degree to which an assessment task could be extrapolated to a real-life target task or could predict the test-takers' performance on the real-situation task (Ellis, 2003). Even though the definition might sound simple, the achievement of this goal can be challenging.

There have been some proposals to improve the authenticity of the assessment, such as Bachman and Palmer's (1996) and Douglas's (2000) frameworks that specify the characteristics that Target Language Use (TLU) tasks, i.e., the realworld tasks and assessment tasks should share. These frameworks are designed to increase the confidence with which the performance in the assessment task could be generalized to the performance in the TLU task. In other words, these frameworks work as a template to show the differences between the assessment task and the real-life tasks. Noroozi (2021) holds that in order to make the best use of this framework, test developers need to standardize the conditions that are fixed in the TLU situation, which would help the generalizability of the assessment. Nevertheless, Ellis (2003) takes issue with this claim, holding that the matching of the assessment task and TLU task might be effective in improving the situational authenticity, yet it cannot enhance the interactional authenticity. Interactional authenticity refers to the quality of interaction between the test-taker, assessment task, and the testing context, while interactional authenticity accounts for the degree of correspondence between the interaction arising from the assessment task and the real-life task (Ellis, 2003). There is also some limitation in this approach since the frameworks per se will not guarantee the improvement of generalizability; it is ultimately left to the test developers' subjective interpretation, judgment, and creative skill to translate the TLU characteristics as perfectly as possible to the assessment tasks.

\section{Direct Measure of Performance}

The distinguishing feature of Task-Based Language Assessment is that the measure of a test-takers' performance is incorporated in the task itself and is not separate from the task. In effect, what makes a test not be an assessment task is exactly this undue separation. Take the example of a test requiring the language learners to listen to a lecture and subsequently answer multiple-choice items. The test is indeed performance-referenced in that it requires learners to process a real-life lecture; however, it is not task-based since the measure of the language performance is not included in the task performance, i.e., the lecture that testees listen to. In fact, the measure of the language performance is indirectly and separately assessed through analyzing the test-takers' answers to the multiple-choice items. It is evident from the example that the measure of students' proficiency must be inherent in and incorporated into the performance of the task; otherwise, the separation of performance measure would question the task-based nature of a test. Therefore, the whole performance of the task is the measure of assessment. In other words, task performance and task measure are the same or inextricably intertwined. While performance is an essential part of assessment tasks, it is not sufficient to ensure that the assessment is truly task-based. Assessment tasks need to be direct to be truly based on the tenets of Task-Based Language Assessment.

\section{E. Criterion-referenced Formative Assessment}


Long (2015) holds that assessment tasks in Task-Based Language Assessment are formative criterion-referenced; that is to say, the students' abilities are not compared with other students yet are evaluated solely based on whether or not they accomplish the task. That is, assessment tasks have not been commonly used for norm-referenced assessment and might not even lend themselves perfectly to this type of assessment. Task-Based Language assessment is more commonly used as a formative assessment; i.e., it is used at the service of the instructional curriculum (Ellis, 2003; Shehadeh, 2012). Assessment tasks can be used for both summative and formative assessment, even though the summative use of Task-Based Language Assessment is not usually associated with language education and, in particular, Task-Based Language Teaching; it is mostly used for vocational and business purposes.

Task-Based Language Assessment provides teachers with the opportunity to investigate multiple aspects of language ability and development, such as accuracy, fluency, complexity, procedural knowledge, and pragmatic proficiency through a single performance (Norris, 2016, as cited in Noroozi, 2021). Therefore, Task-Based Language Assessment offers positive washback effects, which helps the educators and teachers to reconsider how teaching and learning happens. The wash-back effect of Task-Based Language Assessment plays a significant role in improving course content and objectives for the classroom. It also lays the groundwork for learners to receive diagnostic feedback as they can compare their task performance with the clear performance criteria presented to them. Additionally, Task-Based Language Assessment utilizes a variety of outcome reporting formats that are expressed in performance terms, which are more familiar to the non-expert audience. Therefore, Task-Based Language Assessment fosters communication between people who want to use performance information and educational institutions as Task-Based Language Assessment uses performance terms that are more intelligible to them (Brindley, 2013). In other words, Task-Based Language Assessment is capable of producing publically meaningful data that determines the summative functions of the language learning program, such as certification (Norris, 2016).

\section{Challenges in TASK-BASed Language Assessment}

\section{A. Target Language Use}

Task-Based Language Assessment purports to be an authentic method of assessing language performance. To this end, Task-Based Language Assessment needs to utilize assessment tasks that correspond with the real-life target tasks. Therefore, Task-Based Language Assessment needs a set of yardsticks that could ensure the degree of overlap between the assessment tasks and real-life target tasks. To achieve this goal, Bachman and Palmer (1996) put forth a framework of task characteristics that identify the TLU domain. The TLU domain incorporates TLU tasks which indicate a set of criteria to determine the extent to which there is correspondence between the assessment task and the TLU task. They contend that this framework can be applied to describe both the TLU task and assessment task so as to investigate the extent that they converge. Noroozi (2021) contends that the best procedure to use this framework is "to control and fix the testing procedure through a set of different tasks which are representative of the target language domain" (p. 889). It should be noted that this framework not only helps assessment tasks enhance the level of their generalizability but also improves the authenticity of assessment tasks as well as the validity of inferences made by them. Therefore, this framework functions as a yardstick to examine the level of correspondence between the assessment task and the TLU task by describing the TLU domain (Noroozi, 2021). The framework of task characteristics identifies five rubrics: (a) the setting, (b) test rubric, (c) input, (d) the expected response, (e) the relationship between the input and response. Douglas (2000, as cited in Noroozi, 2021), drawing on Bachman and Palmer's framework, makes some adjustments to this framework by adding a new rubric, namely assessment. Besides the TLU situation characteristic framework, Douglas puts forth another framework for language features in the TLU situation. It seems that the framework of the language characteristics would be useful for the construct-based or ability-based approach in the type of language ability, which is required in the TLU situation. Douglas's framework is more inclined towards listing the features of the TLU domain that could be a reference point for the assessment task, while Bachman and Palmer's framework is more predisposed towards specifying the assessment tasks and then describing how they should look like in the TLU situation (Noroozi, 2021).

\section{B. Scoring and Interpretation}

Assessment and scoring of test-takers is a challenging job since assessment tasks inherently do not offer a measure to assess the performance of language learners. Three methods of assessing language learners' performance: (a) direct assessment of tasks performance, (b) discourse analytic measures, and (c) external ratings could be used in Task-Based Language Assessment (Ellis, 2003). Direct assessment includes measuring language learners' performance based on whether they achieve the outcome of the tasks successfully or not. Generally, closed tasks, which have a fixed outcome, lend themselves well to this method of measuring performance, while open tasks, which are subject to the interpretation of the assessor, do not fit well in this method. The discourse analytic method offers a less direct assessment of performance as, in this method, some specific linguistic, sociolinguistic, strategic, and discourse features are highlighted and focused in assessment. Therefore, this method of assessment does not yield an authentic measure of performance since one particular aspect of tasks is derived for assessment. External rating is a method of assessment that involves the assessor's subjective judgment of the learner's performance. This method usually makes use of rating scales to assess performance. These scales are based on the competency and level of performance in assessing language learners' 
performance. Task-Based Language Assessment uses all of these three methods depending on the purpose for which the assessment is to be used. Direct assessment is usually used for vocational purposes where tasks are dichotomously score, such as a pass/fail at the end of a certificate program. The discourse analytic method is mainly used in task-based research, and external ratings is the most commonly used measurement method in Task-Based Language Teaching. External rating is mainly for pedagogical purposes and high stake tests such as IELTS.

\section{DISCUSSION}

The incorporation of the measure of the assessment in the performance of the assessment task is an ideal concept since there is always some reliance on some specific parts of the performance from which the measure is derived for assessment. The feature of directness should be considered as a continuum where on the one extreme, the measure of task performance is perfectly incorporated in the assessment, and on the other, this incorporation is not there. In essence, the more test developers could reach this ideal, the more task-based the assessment would be (see Figure 1). In the same vein, Shehadeh (2012) holds that there is always some degree of induction from the task performance based on the ability underlying the performance; that is, test developers are always bound to stick to the ability that underlies the task performance. This issue is also related to the generalizability of assessment, where assessment scholars attempt to set a framework to define the criteria of measurement in task performance more precisely so as to design assessment tasks and assessment measures that are as close as possible to the real-life situation.

Task-Based Language Assessment

Non-Task-Based Language Assessment

Direct Performance-Referenced C Direct System-Referenced Indirect Performance-Referenced Indirect System-Referenced Assessment Assessment $\quad$ Assessment $\quad$ Assessment

Figure 1. Linear Spectrum of Forms of Task-Based Language Assessment

The degree to which a test is performance-referenced or direct indicates the extent to which it is based on the principles of Task-Based Language Assessment. The feature of directness plays a more significant role in transforming a test into a form of Task-Based Language Assessment than the performance-referenced feature of a test. Therefore, direct tests are closer to the Task-Based Language Assessment end of the spectrum. An assessment task that is direct and performance-referenced is arguably more task-based than the one that is not performance-referenced. In the same vein, the direct performance-referenced tests are more task-based than the direct system-referenced tests that treat language knowledge as a system to be assessed. Since directness is a distinguishing characteristic of Task-Based Language Assessment, both direct performance-referenced and direct system-referenced tests are different forms of Task-Based Language Assessment. The direct performance-referenced tests consist of real-world tasks such as asking students to order pizza on the phone. Direct system-referenced tests refer to the tests such as information-gap or opinion-gap tasks.

Indirect system-referenced tests are not task-based as they do not use tasks in their assessment; in other words, these tests lack both the features of performance-referenced and directness. Discrete-point tests such as multiple-choice tests are an instance of indirect system-referenced tests. The case of indirect performance-referenced tests, for instance, tests of academic language ability, such as TOEFL and IELTS, is a little bit tricky as, on the surface, they could be deemed as task-based tests; however, the measure of assessment is not incorporated in these tests. Thus, the feature of being performance-referenced in these tests does not make these tests task-based. In effect, the mere fact that a test is performance-referenced does not guarantee that it is task-based.

\section{CONCLUSION}

Derived from the principles of Task-Based Language Teaching, Task-Based Language Assessment advocates using authentic assessment tasks that would elicit the type of performance from the students that is close to the real-life situation. However, the goal of Task-Based Language Assessment is not simply using the authentic tasks to elicit certain components of the language system that are then assessed. In fact, Task-Based Language Assessment evaluates the performance of the task as the most important construct or the measure of assessment. Language learners have to perform in order to accomplish the assessment task. Therefore, the performance-referenced feature of Task-Based Language Assessment is one of the necessary features thereof; however, it is not sufficient to distinguish it from other types of assessment. The direct nature of Task-based Language assessment is another important feature that should be retained in any test that purports to be based on the principles of Task-Based Language Assessment. Any derivation from and separation of the criterion measure from the performance of the assessment task undermines the taskness of the assessment task in Task-Based Language teaching.

Hence, for a particular test to be based on the principle of Task-Based Language Assessment, first and foremost, it needs to use an assessment task in the assessment. Second, the measure of assessment must be incorporated into the assessment task. Not being performance-referenced per se does not necessarily make a test less task-based, even though 
it always helps a test be more task-based. Additionally, the settings where the assessment task is performed must correspond as much as possible with the real-life situation in which the authentic real-life task occurs. The assessment rating also determines to what extent the assessment of the tasks corresponds with and predicts the performance in authentic tasks in real-life situations.

\section{IMPLICATIONS}

Task-Based Language Assessment has a couple of benefits for language teachers. As discussed above, Task-Based Language Teaching, as a formative assessment, provides teachers with the chance to fine-tune their syllabus according to the tasks undertaken in real-life situations. Task-Based Language Assessment's positive washback effects allow teachers to learn from their mistakes and improve the effectiveness of their syllabus based on the test-takers' performance on the assessment. In the same vein, Task-Based Language Assessment allows the learners to receive diagnostic feedback as they can compare their task performance with the clear performance criteria presented to them (Noroozi, 2018). Furthermore, Task-Based Language Assessment utilizes various forms of reporting the assessment outcome in terms of performance, which is comprehensible to novice teachers and non-specialists.

More importantly, Task-Based Language Assessment derives its principles from Task-Based Language Teaching; therefore, Task-Based Language Assessment is the best assessment to measure the effectiveness of Task-Based Language Teaching in comparison with other teaching approaches, such as Present, Practice, Produce. This could highlight the significance of Task-Based Language Assessment in the classroom and research. In effect, language teachers can get a better picture of the effectiveness of their Task-Based Instruction through using its relative assessment, that is, Task-Based Language Assessment. This important fact has been to a great extent neglected in the field of second language research since most studies have used other forms of assessment except for Task-Based Language Assessment to assess the effectiveness of Task-Based Language Teaching (e.g., De la Fuente, 2006; De ridder et al., 2007; Gonzalez-Lloret \& Nielson, 2015; Lai et al., 2011; Li et al., 2016; Shintani, 2011, 2013). On the other hand, some studies reported great effects of Task-Based Language Assessment in the L2 classroom (see Winke 2010; Yeh 2010). For instance, Winke (2010) reports the effectiveness of the use of online tasks, as a formative assessment tool, in providing progressive feedback to teachers and language learners.

\section{REFERENCES}

[1] Bachman, L. F. (2002). Some reflections on task-Based language performance assessment. Language Testing, 19, $453-476$. https://doi.org/10.1191/0265532202lt240oa.

[2] Bachman, L. F. (2007). What is the construct? The dialectic of abilities and contexts in defining constructs in language assessment. In J. Fox, M. Wesche, D. Bayliss, L. Cheng, C. Turner, \& C. Doe (Eds.), Language testing reconsidered (pp. $41-$ 71). Ottawa, Canada: University of Ottawa Press.

[3] Bachman, L. F., \& Palmer, A. S. (1996). Language testing in practice. Oxford: Oxford University.

[4] Brindley, G. (1994). Task-centred assessment in language learning programs: The promise and the challenge. In N. Bird, P. Falvey, A. Tsui, D. Allison, A. \& McNeill (Eds.), Language and learning (pp. 73-94). Hong Kong: Institute of Language in Education.

[5] Brindley, G. (2013). Task-Based Assessment. In Chapelle, C. (ed.), The encyclopedia of applied linguistics. Oxford: Wiley Blackwell. https://doi.org/10.1002/9781405198431

[6] Brown, J. D. (2004). Performance assessment: Existing literature and directions for research. Second Language Studies, 22(2), 91-139.

[7] Brown, J. D., Hudson, T. D., Norris, J. M., \& Bonk, W. (2002). Investigating task-based second language performance assessment. Honolulu: University of Hawai'i Press.

[8] Bygate, M. (2016). Sources, developments and directions of task-based language teaching. The Language Learning Journal, 44(4), 381-400. https://doi.org/10.1080/09571736.2015.1039566.

[9] De La Fuente, M., J. (2006). Classroom L2 vocabulary acquisition: Investigating the role of pedagogical tasks and formfocused instruction. Language Teaching Research, 10, 263-95. https://doi.org/10.1191/13621688061r196oa.

[10] De Ridder, I., Vangehuchten, L., \& Gómez, M. S. (2007). Enhancing automaticity through task-based language learning. Applied Linguistics, 28, 309-15. https://doi.org/10.1093/applin/aml057.

[11] Douglas, D. (2000). Assessing language for specific purposes. Cambridge: Cambridge University Press.

[12] Ellis, R. (2003). Task-Based language learning and teaching. Oxford: Oxford University Press.

[13] Ellis, R. (2009). Task-based language teaching: Sorting out the misunderstandings. International journal of applied linguistics, 19(3), 221-246. https://doi.org/10.1111/j.1473-4192.2009.00231.x.

[14] Ellis, R. (2012). Task-based language teaching: Responding to the critics. University of Sydney Papers in TESOL, 8, 1-27.

[15] Ellis, R. (2017). Position paper: moving task-Based language teaching forward. Language Teaching, 50(4), $507-526$. https://doi.org/10.1017/S0261444817000179

[16] Lai, C., Zhao, Y., \& Wang, J. (2011). Task-based language teaching in Online Ab Initio foreign language classrooms. The Modern Language Journal, 95, 81-103. https://oi.org/10.1111/j.1540-4781.2011.01271.x.

[17] Li, S., Ellis, R., \& Zhu, Y. (2016). Task-based versus task-supported language instruction: An experimental study. Annual Review of Applied Linguistics, 36, 205-29. https://doi.org/10.1017/S0267190515000069.

[18] Long, M. (2015). Second language acquisition and task-Based language teaching. Malden, MA: Wiley Blackwell. 
[19] Long, M., \& Norris, J. (2000). Task-Based teaching and assessment. In M. Byram (Ed.), Encyclopedia of language teaching (pp. 597-603). London: Routledge.

[20] McNamara, T. (1996). Measuring second language performance. New York: Longman.

[21] Mislevy, R., Steinberg, L., \& Almond, R. (2002). Design and analysis in task-Based language assessment. Language Testing, 19(4), 477-496. https://doi.org/10.1191/02655322021t241oa.

[22] Noroozi, M. (2018). Task-based language teaching versus present, practice, produce: efficacy in language learning and assessment (Publication No. 3874) [Doctoral Dissertation, Florida International University]. FIU Electronic Theses and Dissertations. https://digitalcommons.fiu.edu/etd/3874.

[23] Noroozi, M. (2021). A survey of the issue of generalizability in task-based language assessment. Theory and Practice in Language Studies, 11(8), 884-890. https://doi.org/10.17507/tpls.1108.03.

[24] Norris, J. M. (2002). Interpretations, intended uses and designs in task-based language assessment. Language Testing, 19(4), 337-346. https://doi.org/10.1191/0265532202lt234ed.

[25] Norris, J. M. (2009). Task-based teaching and testing. In M. H. Long \& C. J. Doughty (Eds.), The handbook of language teaching (pp. 578-94). Malden, MA: Wiley-Blackwell.

[26] Norris, J. M. (2016). Current uses for task-based language assessment. Annual Review of Applied Linguistics, 36, $230-244$. https://doi.org/10.1017/S0267190516000027.

[27] Samuda, V., \& Bygate, M. (2008). Tasks in second language learning. Basingstoke: Palgrave Macmillan. https://doi.org/10.1057/9780230596429.

[28] Shehadeh, A. (2012). Task-based language assessment: Components, development, and implementation. In C. Coombe, P. Davidson, B. O'Sullivan \& S. Stoynoff (Eds.), The Cambridge Guide to Second Language Assessment (pp. 156-163) Cambridge: Cambridge University Press.

[29] Shintani, N. (2011). A comparative study of the effects of input-based and production-based instruction on vocabulary acquisition by young EFL learners. Language Teaching Research, 15, 137-58. https://doi.org/10.1177/1362168810388692.

[30] Shintani, N. (2013). The effect of focus on form and focus on forms instruction on the acquisition of productive knowledge of L2 vocabulary by young beginning-level learners. TESOL Quarterly, 47, 36-62. https://doi.org/10.1002/tesq.54.

[31] Wigglesworth, G. (2008). Task and performance-based assessment. In E. Shohamy \& N. Hornberger (Eds.), Encyclopedia of language and education: Language testing and assessment. Vol. 7: Language testing and assessment. (pp. 111-122) (2nd ed.). New York, NY: Springer.

[32] Winke, P. (2010). Using online tasks for formative language assessment. In A. Shehadeh \& C. Coombe (Eds.), Applications of task-based learning in TESOL (pp. 173-185). Alexandria, VA: TESOL.

[33] Yeh, A. (2010). Assessing task-based activity in a speech training class. In A. Shehadeh \& C. Coombe (Eds.), Applications of task-based learning in TESOL (pp. 161-171). Alexandria, VA: TESOL.

Majeed Noroozi received his Ph.D. in Language Education from Florida International University. His research interests include Task-Based Language Teaching and Bilingualism.

Seyyedmohammad Taheri is a Ph.D. student of Educational Psychology at Texas A\&M University. His research focuses on Task-Based Language Teaching and Corrective Feedback. 